\title{
ANTIBACTERIAL ACTIVITIES OF ANREDERA CORDIFOLIA (TEN.) V. STEENIS LEAVES EXTRACTS AND FRACTIONS
}

\author{
NI PUTU EKA LELIQIA ${ }^{1,2 *}$, ELIN YULINAH SUKANDAR ${ }^{1}$, IRDA FIDRIANNY ${ }^{3}$
}

${ }^{1}$ Department of Pharmacology-Clinical Pharmacy, School of Pharmacy, Bandung Institute of Technology, Indonesia. ${ }^{2}$ Department of Pharmacy, Faculty of Mathematics and Natural Sciences, Udayana University, Indonesia. ${ }^{3}$ Department of Pharmaceutical Biology, School of Pharmacy, Bandung Institute of Technology, Indonesia. Email: leliqia@gmail.com

Received: 22 July 2017, Revised and Accepted: 25 August 2017

ABSTRACT

Objective: This study aims to determine antibacterial activity of Anredera cordifolia leaves extracts and fractions.

Methods: Crude drug was extracted using two methods. First method was extraction by reflux using ethanol $96 \%$ and then fractionated by liquidliquid extraction using n-hexane and ethyl acetate. Second method was gradually extraction by reflux using n-hexane, ethyl acetate and ethanol $96 \%$, respectively. Phytochemical screening was applied to all extracts and fractions, followed by thin-layer chromatography using ursolic acid, oleanolic acid (OA), apigetrin, and rutin as reference substances. A two-fold serial microdilution method was used to determine minimum inhibitory concentration (MIC) against Staphylococcus aureus (ATCC 6538), methicillin-susceptible S. aureus, methicillin resistant S. aureus (MRSA), Bacillus subtilis (ATCC 6633), Bacillus cereus (ATCC 11778), Pseudomonas aeruginosa (ATCC 9027), Escherichia coli (ATCC 8939), E. coli H7 (0156), and ESBL E. coli. Bacteriostatic and bactericidal activities were determined using minimum bactericidal concentration/MIC ratio.

Results: The ethanolic extract, n-hexane and ethyl acetate fractions of $A$. cordifolia from the first method had antibacterial activity against $S$. aureus, MRSA, B. subtilis, and B. cereus (MIC 256-512 $\mu \mathrm{g} / \mathrm{ml}$ ). However, n-hexane and ethyl acetate extract from the second method had broad spectrum of antibacterial activity, which could inhibit the growth of $S$. aureus, MRSA, B. subtilis, P. aeruginosa, and E. coli (MIC 256-512 $\mu \mathrm{g} / \mathrm{ml}$ ). Extracts and fractions showed bacteriostatic and bactericidal activities, but n-hexane extract has most bactericidal activity. Furthermore, steroid/triterpenoid, ursolic, and $\mathrm{OA}$ were found in this extract.

Conclusion: The n-hexane extract from the second method showed the highest antibacterial activity.

Keywords: Anredera cordifolia, Extracts, Fractions, Antibacterial.

(c) 2017 The Authors. Published by Innovare Academic Sciences Pvt Ltd. This is an open access article under the CC BY license (http://creativecommons. org/licenses/by/4. 0/) DOI: http://dx.doi.org/10.22159/ajpcr.2017.v10i12.21503

\section{INTRODUCTION}

Bacterial infections remain as the main leading cause of death, particularly in developing countries [1]. Infection treatment with antibacterial has reduced the morbidity and improved patient's survival with bacterial infections. However, in many cases, the increasing prevalence of strains from common pathogenic bacteria resistance to widely available and affordable antimicrobials is dangerously eroding their effectiveness [2]. Therapeutic options for this case are extremely limited; therefore, it is needed to develop the new antibacterial agent. Antibacterial screening from the plant is an alternative to start the invention of new antibacterial.

Anredera cordifolia (Ten.) v. Steenis has been proven to own pharmacological activity such as gastro protector, antidiabetic, antiobesity, antihyperlipidemic, vasodilator, and wound healer [3-8]. Ethanolic extract of $A$. cordifolia leaves was actively proven to inhibit the growth of some Gram-positive and Gram-negative bacteria such as Bacillus subtilis, Bacillus cereus, Escherichia coli, Pseudomonas aeruginosa, methicillin resistant coagulase negative staphylococci, and methicillin sensitive Staphylococcus aureus (MSSA) [9]. Aqueous extract of A. cordifolia leaves showed inhibition toward B. subtilis, E. coli, S. aureus, and P. aeruginosa growth [10].

Antibacterial activity from A. cordifolia leaves extract, and its fractions have not been reported by the previous researcher. Therefore, in this study, antibacterial activities A. cordifolia extract and its fractions in different solvents were determined toward some pathogen bacteria. This study could show active compounds of $A$. cordifolia leaves as an antibacterial agent.

\section{MATERIALS AND METHODS}

Materials

A. cordifolia dried leaves were collected from Lembang - West Java, Indonesia. Plant identification was confirmed by Herbarium Bandungense, Bandung Institute of Technology. Standard ursolic acid (UA), oleanolic acid (OA), apigetrin, rutin, and antibiotic amoxicillin were obtained from Sigma-Aldrich (USA). Mueller Hinton Broth and Mueller-Hinton Agar were obtained from Oxoid.

The tested microorganisms were obtained from School of Pharmacy, Bandung Institute of Technology, Indonesia, which included five of Gram-positive bacteria such as S. aureus (ATCC 6538), MSSA, methicillin resistant S. aureus (MRSA), B. subtilis (ATCC 6633), and B. cereus (ATCC 11778), and four of Gram-negative bacteria such as P. aeruginosa (ATCC 9027), E. coli (ATCC 8939), E. coli H7 (0156), and ESBL E. coli.

\section{Extraction}

First method of extraction: Crude drug of $A$. cordifolia leaves was extracted by reflux method using ethanol $96 \%$ as a solvent, then vaporated to obtain a thick extract (EE1). Ethanolic extract was added with boiling water and separated in separatory funnel by liquid-liquid extraction method using $\mathrm{n}$-hexane and ethyl acetate solvents. This process produced three fractions at the end n-hexane (HF), ethyl acetate (EAF), and water fraction (WF). The second method of extraction was using gradual extraction. Crude drug was extracted by reflux using n-hexane, ethyl acetate, and ethanol 96\% solvents, respectively, so there were three extracts: n-hexane extract (HE), ethyl acetate extract (EAE), and ethanol extract (EE2). EE1, HF, EAF, WF, HE, EAE, and EE2 were sample in this study. 
Phytochemical screening

The following tests performed on extracts and fractions were to detect the presence of flavonoid, tannin, quinone, saponin, alkaloid, and steroid/triterpenoid, as detailed previously [10]

\section{Detection of UA and $0 A$}

Extracts, fractions, UA, and OA in methanol were spotted on a thin-layer chromatography (TLC) plate. For pre-chromatographic derivatization, the plate was developed in a horizontal chamber with $1 \%$ iodine in chloroform at $1.2 \mathrm{~cm}$ distance. The plate was placed in darkness for 10 minutes and then dried in stream of warm air to remove the excess of iodine [11]. Then, the plate was developed with toluene ethyl acetate formic acid (35:15:1 v/v/v) as the mobile phase. After drying, the plate was sprayed using $\mathrm{H}_{2} \mathrm{SO}_{4}$ reagent and then heated. The visualized spots were documented under visible light.

\section{Detection of apigetrin and rutin}

Extracts, fractions, apigetrin, and rutin in methanol were spotted on a TLC plate. The plate was developed with ethyl acetate methanol water $(7: 1: 1 \mathrm{v} / \mathrm{v} / \mathrm{v})$ as the mobile phase. After that, the dried plate was sprayed using citroborate reagent and then heated. Spots were documented in UV $1366 \mathrm{~nm}$.

Determination of minimum inhibitory concentration (MIC) and minimum bactericidal concentration (MBC)

Extracts and fractions were dissolved in 10\% dimethyl sulfoxide to obtain stock solutions. Standard solution (amoxicillin) was dissolved in sterile water. A two-fold serial microdilution method was used to determine MIC of samples. The lowest concentration that showed no visible growth was regarded as the MIC. Cells from the wells will show no growth of sub-cultured on MHA agar plate to determine the inhibition is reversible or permanent. The MBC was determined as the lowest concentration at which no growth occurred on the plate. The procedure was performed according to the Clinical and Laboratory Standards Institute guidelines [12].

\section{Statistical analysis}

MIC data of extracts, fractions, and amoxicillin against the same bacteria were analysis using Kruskal-Wallis test and continued with MannWhitney for pairwise comparison. $P<0.05$ was considered significant.

\section{RESULTS}

\section{Phytochemical screening}

The result of phytochemical screening of extracts and fractions could be seen in Table 1 .

\section{Detection of UA and OA}

TLC profile of extracts and fractions toward the existence of UA (Rf 0.61) and OA (Rf 0.72) showed that EE1, HF, and HE contained both of those acids (Fig. 1).

Detection of apigetrin and rutin

TLC resulted that qualitatively analyze the existence of apigetrin (Rf 0.50) and rutin (Rf 0.25) could be seen in Fig. 2. Based on the

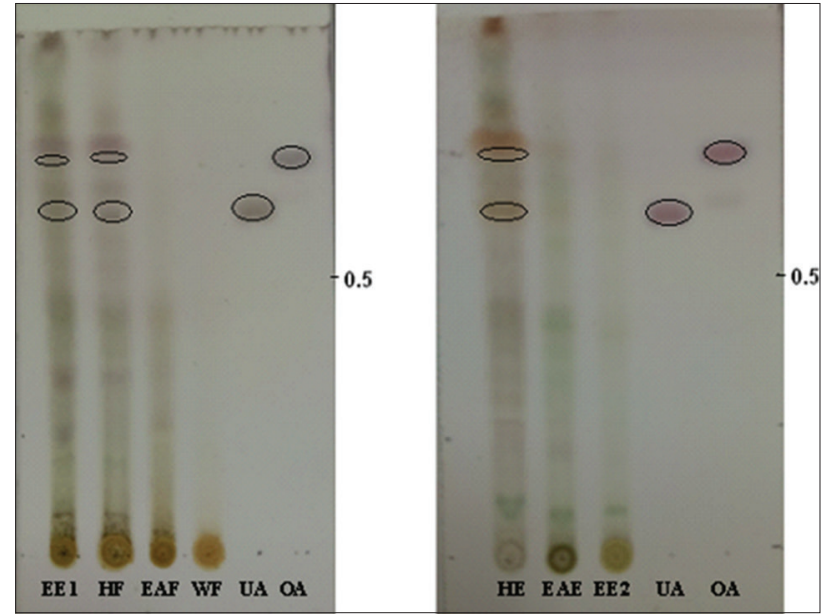

Fig. 1: Thin-layer chromatography profile of Anredera cordifolia leaves extract and fractions for detecting ursolic acid and oleanolic acid (after spraying with $\mathrm{H}_{2} \mathrm{SO}_{4}$ reagent, under visible light). Tracks: Ethanolic extract from $1^{\text {st }}$ extraction (EE1), n-hexane fraction (HF), ethyl acetate fraction (EAF), water fraction (WF), and $n$-hexane extract (HE); ethyl acetate extract (EAE), ethanolic extract from $2^{\text {nd }}$ extraction (EE2), ursolic aid (UA), and oleanolic acid (OA)

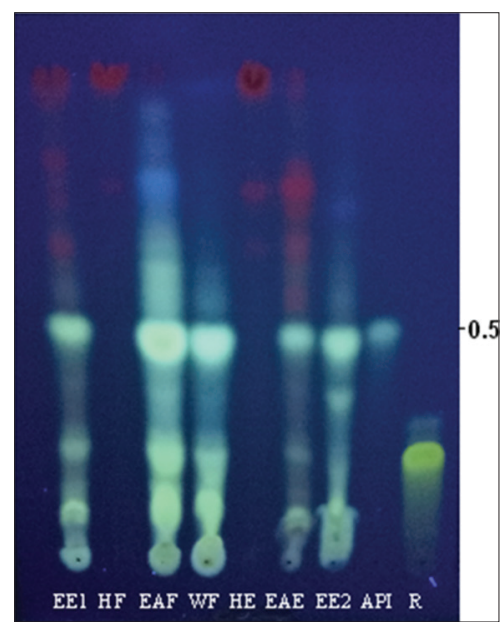

Fig. 2: Thin-layer chromatography profile of Anredera cordifolia leaves extract and fractions for detecting apigetrin and rutin (after spraying with citroborate reagent, under UV $1366 \mathrm{~nm}$ ). Tracks: Ethanolic extract from $1^{\text {st }}$ extraction (EE1), hexane fraction (EF), ethyl acetate fraction (EAF), water fraction (WF), and hexane extract (HE); ethyl acetate extract (EAE), ethanolic extract from $2^{\text {nd }}$ extraction (EE2), apigetrin (API), and rutin (R)

Table 1: Phytochemical screening of Anredera cordifolia extracts and fractions

\begin{tabular}{|c|c|c|c|c|c|c|}
\hline Sample & Flavonoid & Tannin & Quinone & Saponin & Alkaloid & Steroid/triterpenoid \\
\hline \multicolumn{7}{|l|}{ First extraction method } \\
\hline Ethanolic extract (EE1) & + & - & - & + & + & + \\
\hline N-hexane fraction (HF) & - & - & - & - & - & + \\
\hline Ethyl acetate fraction (EAF) & + & - & - & - & + & + \\
\hline Water fraction (WF) & + & - & - & + & + & + \\
\hline \multicolumn{7}{|l|}{ Second extraction method } \\
\hline $\mathrm{N}$-hexane extract (HE) & - & - & - & - & - & + \\
\hline Ethanolic extract (EE2) & + & - & - & + & + & + \\
\hline
\end{tabular}

+: Detected, -: Not detected 
Table 2: Antibacterial activities of $A$. cordifolia extracts and fractions

\begin{tabular}{|c|c|c|c|c|c|c|c|c|}
\hline \multirow{2}{*}{$\begin{array}{l}\text { Bacterial species } \\
(\mu \mathrm{g} / \mathrm{ml})\end{array}$} & \multicolumn{4}{|c|}{$1^{\text {st }}$ extraction method } & \multicolumn{3}{|c|}{$2^{\text {nd }}$ extraction method } & \multirow[t]{2}{*}{ Amoxicillin } \\
\hline & EE1 & HF & EAF & WF & HE & EAE & EE2 & \\
\hline \multicolumn{9}{|l|}{ S. aureus } \\
\hline MBC & $>4096$ & $>4096$ & $>4096$ & $>4096$ & $256^{a *}$ & $>4096$ & $>4096$ & 0.5 \\
\hline \multicolumn{9}{|l|}{ MSSA } \\
\hline MIC & 2048 & 2048 & 4096 & $>4096$ & 1024 & 4096 & 4096 & 8 \\
\hline MBC & $>4096$ & 4096 & $>4096$ & $>4096$ & 2048 & $>4096$ & $>4096$ & 8 \\
\hline \multicolumn{9}{|l|}{ MRSA } \\
\hline MIC & $512^{\mathrm{a}}$ & 1024 & 1024 & $>4096$ & $512^{\mathrm{a}}$ & $512^{\mathrm{a}}$ & 4096 & $32 * *$ \\
\hline MBC & $>4096$ & 2048 & 2048 & $>4096$ & 1024 & 1024 & $>4096$ & 32 \\
\hline \multicolumn{9}{|l|}{ B. subtilis } \\
\hline MIC & 2048 & $512^{\mathrm{a}}$ & 1024 & $>4096$ & $512 \mathrm{a}$ & $512^{\mathrm{a}}$ & 4096 & $4^{* *}$ \\
\hline MBC & 4096 & 4096 & 4096 & $>4096$ & 1024 & $>4096$ & $>4096$ & 4 \\
\hline \multicolumn{9}{|l|}{ B. cereus } \\
\hline MIC & $>4096$ & $512^{\mathrm{a}}$ & $>4096$ & $>4096$ & 1024 & 2048 & 4096 & $0.5^{* *}$ \\
\hline $\mathrm{MBC}$ & $>4096$ & 1024 & $>4096$ & $>4096$ & 2048 & $>4096$ & $>4096$ & 2 \\
\hline \multicolumn{9}{|l|}{ P. aeruginosa } \\
\hline MIC & 1024 & $>4096$ & $>4096$ & $>4096$ & $256^{a *}$ & 1024 & 4096 & $16^{* *}$ \\
\hline MBC & 2048 & $>4096$ & $>4096$ & $>4096$ & $512^{\mathrm{a}}$ & 4096 & $>4096$ & 32 \\
\hline \multicolumn{9}{|l|}{ E. coli } \\
\hline MIC & $>4096$ & $>4096$ & $>4096$ & $>4096$ & $512^{\mathrm{a} *}$ & 4096 & $>4096$ & $1^{* *}$ \\
\hline $\mathrm{MBC}$ & $>4096$ & $>4096$ & $>4096$ & $>4096$ & 2048 & $>4096$ & $>4096$ & 1 \\
\hline \multicolumn{9}{|l|}{ E. coli H7 (0156) } \\
\hline MIC & $>4096$ & 2048 & $>4096$ & $>4096$ & $>4096$ & 4096 & 4096 & 32 \\
\hline MBC & $>4096$ & 4096 & $>4096$ & $>4096$ & $>4096$ & $>4096$ & $>4096$ & 32 \\
\hline \multicolumn{9}{|l|}{ ESBL $E$. coli } \\
\hline MIC & 4096 & 1024 & 2048 & $>4096$ & 2048 & 4096 & $>4096$ & $>256$ \\
\hline $\mathrm{MBC}$ & $>4096$ & 2048 & 4096 & $>4096$ & 4096 & $>4096$ & $>4096$ & $>256$ \\
\hline
\end{tabular}

Experiment was conducted triplicate. EE1: Ethanolic extract of A.cordifolia leaves from $1^{\text {st }}$ extraction method, HF: n-hexane fraction, EAF: Ethyl acetate fraction, WF: Water fraction, HE: $n$-hexane extract, EAE: Ethyl acetate extract, EE2: Ethanolic extract from $2^{\text {nd }}$ extraction method, MIC: Minimum inhibitory concentration,

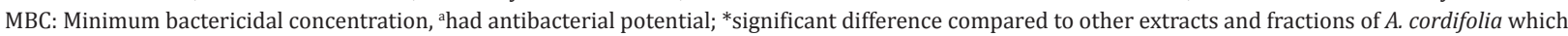
had antibacterial potential against the same bacteria $(\mathrm{p}<0.05)$; ${ }^{* *}$ Significant difference compared to extracts and fractions of $A$. cordifolia which had antibacterial potential against the same bacteria $(\mathrm{p}<0.05)$. A. cordifolia: Anredera cordifolia, MSSA: Methicillin sensitive Staphylococcus aureus, MRSA: Methicillin resistant Staphylococcus aureus, ESBL: Extended-spectrum beta-lactamases, E. coli: Escherichia coli, P. aeruginosa: Pseudomonas aeruginosa, B. cereus: Bacillus cereus, B. subtilis: Bacillus subtilis, S. aureus: Staphylococcus aureus

observation, EE1, EAF, WF, and EAE contained apigetrin and rutin. Meanwhile, EE2 only contained apigetrin.

Determination of MIC and MBC

Antibacterial activities of the sample were presented in Table 2. Extracts and fractions had antibacterial potential if their MIC value was $<1024 \mu \mathrm{g} / \mathrm{ml}$

\section{DISCUSSION}

Biologically active compounds commonly occur in low concentration in plants. An extraction technique is able to obtain an extract with high yield and with minimum changes in functional properties of the required extract. Several studies have reported variations in the biological activities of extracts prepared using different extraction techniques [13-15]. Antibacterial activity test from $1^{\text {st }}$ extraction method (ethanol extract and its fraction) showed that they could only inhibit Gram-positive bacteria. HF could inhibit three microorganisms, S. aureus (MIC $256 \mu \mathrm{g} / \mathrm{ml}$ ), B. subtilis, and B. cereus (MIC $512 \mu \mathrm{g} / \mathrm{ml}$ ). Meanwhile, EE1 could only inhibit the growth of two microorganisms, S. aureus and MRSA (MIC $512 \mu \mathrm{g} / \mathrm{ml}$ ); EAF could only inhibit the growth of $S$. aureus (MIC $512 \mu \mathrm{g} / \mathrm{ml}$ ). The WF had no antibacterial activity. Meanwhile from $2^{\text {nd }}$ extraction showed broader antibacterial activity. HE could inhibit three Gram-positive bacteria, S. aureus (MIC $256 \mu \mathrm{g} / \mathrm{ml}$ ), MRSA, and B. subtilis (MIC $512 \mu \mathrm{g} / \mathrm{ml}$ ) and two Gram-negative bacteria, P. aeruginosa (MIC $256 \mu \mathrm{g} / \mathrm{ml}$ ) and E. coli (MIC $512 \mu \mathrm{g} / \mathrm{ml}$ ). Only HE could inhibit Gram-negative bacteria, and its activity was significantly different compared the other extracts and fractions $(\mathrm{p}<0.05)$. EAE could inhibit $S$. aureus, MRSA, and B. subtilis (MIC $512 \mu \mathrm{g} / \mathrm{ml}$ ). EE2 had no antibacterial activity. Antibacterial activities of HF and HE against $S$. aureus were significantly higher than other extracts and fractions of A. cordifolia $(\mathrm{p}<0.05)$.
Amoxicillin was used as standard in this research. Its activities against all bacteria were the highest and significantly different compared to extracts and fractions of $A$. cordifolia, $(\mathrm{p}<0.05)$. Amoxicillin is shown to be effective against a wide range of infections caused by wide range of Gram-positive and Gram-negative bacteria [16]. Amoxicillin is still being drug of choice within the class because it has better pharmacokinetic than other $\beta$-lactam antibiotics for the treatment of infections due to susceptible organisms [17].

Based on MBC to MIC ratio of the sample which had antibacterial potential (MIC $<1024 \mu \mathrm{g} / \mathrm{ml}$ ), some sample were known to have bacteriostatic and bactericidal activity. Bacteriostatic activity has been defined as a ratio of MBC to MIC $>4$ and bactericidal activity had ratio $\mathrm{MBC}$ to $\mathrm{MIC}<4$ [18]. In this study, EE1 and EAE had bacteriostatic activity, while HF and HE had bactericidal activity except its activity toward B. cereus and P. aeruginosa. EAE only had bactericidal activity toward MRSA. HE had the highest antibacterial activity among all extracts and fractions of $A$. cordifolia leaves.

The chemical constituents in plants or extracts are known to be biologically active ingredients. Some chemical constituents are considered as secondary metabolites components. They are directly responsible for different activity. Saponin was found in AF and EE1 that was obtained from first and second extraction methods. Flavonoid and alkaloid were found in most samples, except in HF dan HE. All samples contained steroid/triterpenoid. Some research showed that flavonoid, saponin, alkaloid, and steroid/triterpenoid had antibacterial activity [19-23]

TLC result showed that EE1, HF, and HE (Fig. 1) contained ursolic acid and OA. Several studies had proven that ursolic acid could inhibit the growth of pathogen bacteria such as B. cereus, S. aureus, P. aeruginosa, E. 
coli, and MRSA [24-26]. Apigetrin and rutin that were available in EE1, EAF, and EAE (Fig. 2), were also had been proven as antibacterial in few studies. Tripleurospermum disciforme aerial part extracts that contained apigetrin, demonstrated antibacterial activity against S. aureus [27]. Rutin could inhibit growth of $S$. aureus, B. subtilis, and MRSA [28-29].

\section{CONCLUSION}

The HE had the highest antibacterial activity. Phytochemical screening of the extract showed the presence of steroid/triterpenoid. Ursolic acid and OA that have been known to have antibacterial activity from previous research were found in this extract. In addition, HE had more bactericidal activity compared to others samples. This study could be used to determine the active compounds of $A$. cordifolia as antibacterial agent for the future research.

\section{ACKNOWLEDGMENTS}

This research was funded by Ministry of Research, Technology and Higher Education of The Republic of Indonesia of The Republic of Indonesia through Doctoral Dissertation Grant.

\section{REFERENCES}

1. World Health Organization. Antimicrobial Resistance from World Health Organization. Available from: http://www.who.int/mediacentre/ factsheets/fs194/en. [Last accessed on 2017 Apr 24].

2. World Health Organization. WHO Model Prescribing Information: Drugs Used in Bacterial Infections. Available from: http://www.apps. who.int/medicinedocs/en/d/Js5406e; http://www.who.int/mediacentre/ factsheets/fs194/en. [Last accessed on $2017 \mathrm{Apr} 24$ ].

3. Horng CT, Chao HR, Lee CF, Hsueh CW, Chen FA. Gastro protective effect of Madeira vine against ethanol-induced gastric mucosal lesion in rat. Asian J Chem 2012;24(2):765-8.

4. Elya B, Handayani R, Sauriasari R, Azizahwati, Hasyyati US, Permana IT, et al. Antidiabetic activity and phytochemical screening of extracts from Indonesian plants by inhibition of alpha amylase, alpha glucosidase and dipeptidyl peptidase IV. Pak J Bio Sci 2015;18(6):279-84.

5. Lestari D, Sukandar EY, Fidrianny I. Anredera cordifolia leaves extract as antihyperlipidemia and endothelial fat content reducer in male Wistar rat. Int J Pharm Clin Res 2015;7(6):435-9.

6. Sukandar EY, Ridwan A, Sukmawan YP. Vasodilatation effect of ethanolic extract of Anredera cordifolia, Sonchus arvensis L, and ursolic acid on isolated rabbit aortic and frog heart. Int J Pharm Pharm Sci 2016;8(2):145-9.

7. Sukandar EY, Kurniati NF, Nurdianti AN. Antiobesity effect of ethanol extract of Anredera cordifolia (Ten.) Steenis leaves on obese male Wistar rats induced by high-carbohydrate diet. Int J Pharm Pharm Sci 2016;8(4):171-3

8. Yuliani SH, Fudholi A, Pramono S, Marchaban. The effect of formula to physical properties of wound healing gel of ethanolic extract of binahong (Anredera cordifolia (Ten.) Steenis). Int J Pharm Sci Res 2012;27(3):4254-9.

9. Garmana AN, Sukandar EY, Fidrianny I. Activity of several plant extracts against drug-sensitive and drug-resistant microbes. Procedia Chem 2012;13:164-9.

10. Alonso Paz E, Cerdeiras MP, Fernandez J, Ferreira F, Moyna P,
Soubes M, et al. Screening of Uruguayan medicinal plants for antimicrobial activity. J Ethnopharmacol 1995;45(1):67-70

11. Wójciak-Kosior M. Separation and determination of closely related triterpenic acids by high performance thin-layer chromatography after iodine derivatization. J Pharm Biomed Anal 2007;45(2):337-40.

12. CLSI. Methods for Dilution Antimicrobial Susceptibility Tests for Bacteria that Grow Aerobically; Approved Standard. CLSI Document M07-A9. $9^{\text {th }}$ ed., Vol. 32. Wayne, PA: Clinical and Laboratory Standards Institute; 2012. p. 18-9.

13. Hayouni EA, Abedrabba M, Bouix M, Hamdi M. The effects of solvents and extraction method on the phenolic contents and biological activities in vitro of Tunisian Quercus coccifera L. and Juniperus phoenica L. Fruit extracts. Food Chem 2007;105:1126-34.

14. Abah SE, Egwari LO. Methods of extraction and antimicrobial susceptibility testing of plant extracts. Afr J Basic Appl Sci 2011;3(5):205-9.

15. Abdelfadel MM, Khalaf HH, Sharoba AM, Assous MT. Effect of extraction methods on antioxidant and antimicrobial activities of some spices and herbs extracts. J Food Technol Nutr Sci 2016;1(1):1-14.

16. Kaur SP, Rao R, Nanda S. Amoxicillin: A broad spectrum antibiotic. Int J Pharm Pharm Sci 2011;3(3):30-7.

17. Shahhet $L, A$ Araghban $D$, Chehna D. Improvement of the physicochemical properties of amoxicillin trihydrate powder by recrystallization at different $\mathrm{pH}$ values. Int J Pharm Pharm Sci 2011;3(3):1-9.

18. Pankey GA, Sabath LD. Clinical relevance of bacteriostatic versus bactericidal mechanisms of action in the treatment of Gram-positive bacterial infections. Clin Infect Dis 2004;38(6):864-70.

19. Cushnie TP, Lamb AJ. Antimicrobial activity of flavonoids. Int J Antimicrob Agents 2005;26(5):343-56.

20. Moussaoui F, Zellagui A, Segueni N, Touil A, Rhouati S. Flavonoid constituents from Algerian Launaea resedifolia (O.K.) and their antimicrobial activity. Rec Nat Prod 2010;4(1):91-5.

21. Lunga PK, Qin XJ, Yang XW, Kuiate JR, Du ZZ, Gatsing D. Antimicrobial steroidal saponin and oleanane-type triterpenoid saponins from Paullinia pinnata. BMC Complement Altern Med 2014;14:369.

22. Maatalah MB, Bouzidi NK, Bellahouel S, Merah B, Fortas Z, Soulimani R, et al. Antimicrobial activity of the alkaloids and saponin extracts of Anabasis articulate. J Biotechnol Pharm Res 2012;3(3):54-7.

23. Cushnie TP, Cushnie B, Lamb AJ. Alkaloids: An overview of their antibacterial, antibiotic-enhancing and antivirulence activities. Int $\mathrm{J}$ Antimicrob Agents 2014;44(5):377-86.

24. Fontanay S, Grare M, Mayer J, Finance C, Duval RE. Ursolic, oleanolic and betulinic acids: Antibacterial spectra and selectivity indexes. J Ethnopharmacol 2008;120(2):272-6.

25. Kim SG, Kim MJ, Jin D, Park SN, Cho E, Freire MO, et al. Antimicrobial effect of ursolic acid and oleanolic acid against methicillin resistant Staphylococcus aureus. Korean J Microbiol 2012;48(3):212-5.

26. do Nascimento PG, Lemos TL, Bizerra AM, Arriaga ÂM, Ferreira DA, Santiago GM, et al. Antibacterial and antioxidant activities of ursolic acid and derivatives. Molecules 2014;19(1):1317-27.

27. Tofighia Z, Molazema M, Doostdarb B, Tabanb P, Shahverdic AR, Samadi N, et al. Antimicrobial activities of three medicinal plants and investigation of flavonoids of Tripleurospermum disciforme. Iran J Pharm Res 2015;14(1):225-31.

28. Orhan DD, Ozçelik B, Ozgen S, Ergun F. Antibacterial, antifungal, and antiviral activities of some flavonoids. Microbiol Res 2010;165(6):496-504.

29. Dubey S, Ganeshpurkar A, Bansal D, Dubey N. Experimental studies on bioactive potential of rutin. Chron Young Sci 2013;4:153-7. 